\title{
PENGARUH GENDER DAN TINGKAT PENDIDIKAN TERHADAP KEPATUHAN WAJIB PAJAK DI WILAYAH KANTOR PELAYANAN PAJAK PRATAMA TAHUNA
}

\author{
Erica Kakunsi ${ }^{1}$, Sifrid Pangemanan ${ }^{2}$, Winston Pontoh ${ }^{3}$ \\ ${ }^{1,2,3}$ Fakultas Ekonomi dan Bisnis. Jurusan Akuntansi. Universitas Sam Ratulangi, Jl. Kampus Bahu, Manado, \\ 95115, Indonesia. \\ E-mail : ericaangela.kakunsi@gmail.com
}

\begin{abstract}
This study aims to determine whether Gender and Education have an influence on taxpayer compliance with Tahuna prison service office. Compliance is a major issue of the application of the Self Assessment System. Taxpayers are entrusted by the Directorate General of Taxation to meet its tax obligations, Gender and Education Level is one of the factors that determine the behavior. The research method used is quantitative research using research and cross questionnaires to 51 individual taxpayers. Data were analyzed using ANOVA and the results showed that gender can not influence. With educational levels that have an effect on mandatory personal compliance. Will Gender and Education have no relationship in affect. The importance of education level in its implementation can be followed up by the DGT through ongoing socialization, tax counseling, taxation seminars and training, etc.
\end{abstract}

Keywords: Gender, Education Level, and Tax Compliance

\section{PENDAHULUAN}

Bangsa Indonesia adalah bangsa yang menjunjung tinggi hak dan kewajiban setiap warga negara yang berdasarkan Pancasila dan Undang-Undang Dasar 1945. Oleh sebab itu, perpajakan ditempatkan negara sebagai perwujudan kewajiban kenegaraan dalam rangka peran aktif masyarakat untuk membiayai pembangunan. Salah satu usaha untuk mewujudkan kemandirian suatu bangsa dalam pembiayaan pembangunan yaitu menggali sumber dana yang berasal dari dalam negeri berupa pajak, dan tidak dapat dipungkiri bahwa pajak telah memberikan kontribusi terbesar dalam penerimaan negara terutama untuk menopang pembiayaan penyelenggaran pemerintahan dan pembangunan nasional.

Langkah pemerintah untuk terus meningkatkan penerimaan dari sektor pajak yaitu dengan menerapkan sistem pemungutan pajak self assessment system. Penerapan self qssessment system membuat tanggung jawab wajib pajak semakin besar. Tanggung jawab ini menyangkut kesadaran wajib pajak untuk memenuhi kewajibannya. Oleh karena itu, kepercayaan yang telah diberikan oleh negara haruslah diimbangi dengan kesadaraan yang memadai. Dalam hal inilah kepatuhan pajak semakin memegang peranan dalam upaya efektivitas berjalannya self assessment system (Debbianita dan Carolina, 2013).

Kepatuhan pajak dapat didefinisikan sebagai suatu sikap/ perilaku seorang wajib pajak yang melaksanakan semua kewajiban perpajakannya dan menikmati semua hak perpajakannya sesuai dengan ketentuan peraturan perundangan yang berlaku (Debbianita dan Carolina, 2013). Oleh karena itu, sangat penting apabila kepatuhan wajib pajak dapat timbul dari diri wajib pajak itu sendiri atau secara sukarela. Wajib pajak patuh bukan berarti wajib pajak membayar dalam nominal besar, melainkan wajib pajak yang mengerti dan mematuhi hak dan kewajibannya dalam bidang perpajakan serta telah memenuhi kriteria-kriteria tertentu (Supriyati dan Hidayati dalam Fitriyani, dkk 2014).

Kepatuhan pajak sangat terikat dengan karakteristik seorang wajib pajak. Centre for Tax Policy and Administration (2004) mengidentifikasikan faktor-faktor yang dapat 
mempengaruhi perilaku kepatuhan wajib pajak, diantaranya faktor individual seperti gender dan tingkat pendidikan. Istilah gender dikaitkan dengan perbedaan jenis kelamin. Disimpulkan oleh Al-Mamun et al. (2014) bahwa tidak ada perbedaan signifikan dalam hal kepatuhan perpajakan antara laki-laki dan perempuan. Dalam penelitian Hai dan See (2011) menunjukkan, bahwa terdapat pengaruh yang positif gender terhadap kepatuhan wajib pajak.

Pengetahuan terhadap perpajakan secara umum belum menyeluruh menyentuh dunia pendidikan. Pendidikan juga dapat mempengaruhi kepatuhan perpajakan. Pengaruh pendidikan bisa menguntungkan atau tidak menguntungkan. Orang berpendidikan akan lebih memahami peluang untuk melakukan penggelapan pajak sehingga dapat memengaruhi perilaku kepatuhan perpajakan mereka (Lewis, 1982). Di sisi lain, orang-orang yang berpendidikan cenderung lebih memiliki pengetahuan tentang manfaat pajak sehingga dapat meningkatkan kepatuhan mereka.

Menurut Menurut Al-Mamun et al. (2014), tingkat pendidikan yang tinggi menunjukkan tingkat etika dan moral pajak yang tinggi pula. Maryati (2014) menyatakan bahwa terdapat pengaruh yang signifikan antara tingkat kepatuhan terhadap kepatuhan wajib pajak. Namun dalam penelitian Amilin dan Yusronillah (2009) menunjukkan bahwa tingkat pendidikan tidak memiliki pengaruh terhadap motivasi memenuhi kewajiban pajak.

Berdasarkan uraian diatas, maka tujuan dari penelitian ini yaitu untuk mengkaji dan mengetahui pengaruh Gender terhadap kepatuhan wajib pajak; dan untuk mengkaji dan mengetahui pengaruh Tingkat Pendidikan terhadap kepatuhan wajib pajak.

\section{TINJAUAN PUSTAKA}

\subsection{Pengertian Akuntansi Perpajakan}

Pengertian akuntansi pajak menurut Agoes dan Estralita (2013:10) adalah menetapkan besarnya pajak terutang berdasarkan laporan keuangan yang disusun oleh perusahaan. Proses akuntansi dimulai adanya transaksi, yaitu peristiwa yang dapat mengakibatkan berubahnya posisi keuangan perusahaan. Transaksi inilah yang menjadi atensi pemerintah dalam mengeluarkan peraturan-peraturan perpajakan agar dapat memungut pajak atas transaksi untuk membiayai pembangunan di Indonesia. Dengan adanya titik ketersinggungan akuntansi dan pajak ini, yaitu transaksi, perusahaan cenderung menerapkan akuntansi yang sudah sesuai dengan peraturan pajak atau disebut dengan istilah akuntansi pajak (Tax Accounting) (Lubis 2015: 2 dikutip dalam Pontoh, Elim dan Budiarso, 2017).

\subsection{Pengertian Pajak}

Menurut Undang-Undang No. 28 tahun 2007, pajak adalah kontribusi wajib kepada negara yang terutang oleh orang pribadi atau badan yang bersifat memaksa berdasarkan Undang-Undang, dengan tidak mendapatkan imbalan secara langsung dan digunakan untuk keperluan negara bagi sebesar-besarnya kemakmuran rakyat. Dengan demikian pajak merupakan penerimaan negara dan kewajiban bagi setiap wajib pajak.

\subsection{Sistem Pemungutan Pajak}

Sistem pemungutan pajak menurut Sumarsan (2014: 14) dapat dibagi menjadi :

1. Official Assessment System. Adalah suatu sistem pemungutan yang memberi wewenang kepada pemerintah (fiskus) untuk menentukan besarnya pajak yang terutang. Ciri-ciri Official Assessment System :

a.Wewenang untuk menentukan besarnya pajak terutang berada pada fiskus;

b.Wajib pajak bersifat pasif [dalam hal menghitung besarnya pajak terutang];

c.Utang pajak timbul setelah dikeluarkan surat ketetapan pajak oleh fiskus.

2. Self Assessment System. Adalah suatu sistem pemungutan pajak yang memberi wewenang, kepercayaan, tanggung jawab kepada wajib pajak untuk menghitung, memperhitungkan, membayar, dan melaporkan sendiri besarnya pajak yang harus di bayar. 
3. Withholding System. Adalah suatu sistem pemungutan pajak yang memberi wewenang kepada pihak ketiga [bukan fiskus ataupun Wajib Pajak yang bersangkutan] untuk memotong atau memungut besarnya pajak yang terutang oleh Wajib Pajak.

\subsection{Kepatuhan Wajib Pajak}

Menurut Keputusan Menteri Keuangan No. 544/KMK.04/2000, kepatuhan Wajib Pajak dapat didefinisikan dari :

"Tepat waktu dalam menyampaikan SPT untuk semua jenis pajak dalam dua tahun terakhir, tidak mempunyai tunggakan pajak untuk semua jenis pajak, kecuali telah memperoleh izin untuk mengangsur atau menunda pembayaran pajak, tidak pernah dijatuhi hukuman karena melakukan tindak pidana di bidang perpajakann dalam jangka waktu 10 tahun terakhir, dalam 2 tahun terakhir menyelenggarakan pembukuan dan dalam hal terhadap wajib pajak pernah dilakukan pemeriksaan, koreksi pada pemeriksaan yang terkhir untuk masing-masing jenis pajak yang terutang palling banyak 5\%, wajib pajak yang laporan keuangannya untuk 2 tahun terakhir diaudit oleh akuntan publik dengan pendapat wajar tanpa pengecualian, atau pendapat dengan pengecualian sepanjang tidak mempengaruhi laba rugi fiskal".

\subsubsection{Kriteria Wajib Pajak Patuh}

Menteri Keuangan Republik Indonesia mengeluarkan peraturan yang tercantum di dalam No.74/PMK.03/2012 Pasal 2 sebagai syarat untuk masuk kedalam kriteria Wajib Pajak yang patuh:

1. Tepat waktu dalam menyampaikan Surat Pemberitahuan

2. Tidak mempunyai tunggakan pajak untuk semua jenis pajak, kecuali tunggakan pajak yang telah memperoleh izin mengangsur atau menunda pembayaran pajak

3. Laporan Keuangan diaudit oleh akuntan public atau lemabaga pengawasan keuangan pemerintah dengan pendapat wajar tanpa pengecualian selama 3 (tiga) tahun berturutturut

4. Tidak pernah dipidana Karena melakukan tindak pidana dibidang perpajakan berdasarkan putusan pengadilan yang telah mempunyai kekuatan hokum tetap dalam jangka waktu 5 (lima) tahun terakhir.

\subsection{Gender}

Centre for Tax Policy and Administration (2004) mengidentifikasikan faktor-faktor yang dapat mempengaruhi perilaku kepatuhan wajib pajak diantaranya faktor individual seperti gender. Hal ini juga didukung oleh penelitian menurut Ganda Frisno Rasaribu dan Christine Tjen (2016) yang menyebutkan faktor-faktor demografi terhadap kepatuhan perpajakan di Indonesia diantaranya yaitu gender.

Gender merupakan salah satu faktor yang menarik untuk diteliti terkait kepatuhan pajak. Beberapa penelitian menunjukan hasil bahwa Wajib Pajak Wanita akan patuh membayar pajak dengan alas an hati nurani atau memiliki perasaan bersalah jika tidak membayar pajak sesuai dengan jumlah yang seharusnya, sedangkan Wajib pajak pria lebih menekankan pada ketakutan pada sanksi yang diberlakukan (Debbianita dan Verani Carolina, 2013).

\subsection{Tingkat Pendidikan}

Pendidikan dalam Kamus Besar Bahasa Indonesia (2008) yaitu proses perubahan sikap dan tata laku sesorang atau sekelompok orang dalam usaha mendewasakan manusia melalui upaya pengajaran dan pelatihan. Di dalam Undang-Undang Republik Indonesia pasal 1 Nomor 20 Tahun 2003 tentang Pendidikan Nasional, pengertian pendidikan adalah usaha sadar dan terencana untuk mewujudkan suasana belajar dan proses pembelajaran agar peserta didik secara aktif mengembangkan potensi dirinya untuk memiliki kekuatan spiritual keagamaan, pengendalian diri, kepribadian, kecerdasan, akhlak mulia, serta keterampilan yang diperlukan dirinya, masyarakat, bangsa dan negara (Sisdiknas, 2003). 
Tingkat pendidikan adalah tahapan pendidikan yang ditetapkan berdasarkan tingkat perkembangan peserta didik, tujuan yang akan dicapai dan kemauan yang dikembangkan. Tingkat pendidikan berpengaruh terhadap perubahan sikap dan perilaku hidup sehat. Tingkat pendidikan yang lebih tinggi akan memudahkan sesorang atau masyarakat untuk menyerap informasi dan mengimplementasikannya dalam perilaku dan gaya hidup sehari-hari, khususnya dalam hal kesehatan. Pendidikan formal membentuk nilai bagi seseorang terutama dalam menerima hal baru.

\subsubsection{Indikator-Indikator Tingkat Pendidikan}

Menurut UU SISDIKNAS No. 20 (2003), indikator tingkat pendidikan terdiri dari jenjang pendidikan dan kesesuaian jurusan. Jenjang pendidikan adalah tahapan pendidikan yang ditetapkan berdasarkan tingkat perkembangan peserta didik, tujuan yang akan dicapai, dan kemampuan yang dikembangkan, terdiri dari:

a. Pendidikan dasar: Jenjang pendidikan awal selama 9 tahun (Sembilan) tahun pertama masa sekolah anak-anak yang melandasi jenjang pendidikan menengah.

b. Pendidikan menengah: Jenjang pendidikan lanjutan pendidikan dasar.

c. Pendidikan tinggi: jenjang pendidikan setelah pendidikan menengah yang mencakup program sarjana, magister, doctor, dan spesialis yang diselenggarakan oleh perguruan tinggi.

\subsection{Hipotesis}

Sugiyono (2013: 96) menyatakan bahwa hipotesis merupakan jawaban sementara terhadap rumusan masalah penelitian, dimana rumusan masalah dinyatakan dalam bentuk kalimat pertanyaan. Hipotesis merupakan hasil pemikiran rasional yang dilandasi oleh teori, dalil, hukum dan sebagainya yang sudah ada sebelumnya. Hipotesis dapat juga berupa pernyataan yang menggambarkan atau memprediksi hubungan-hubungan tertentu diantara dua variable atau lebih, yang kebenaran hubungan tersebut tunduk pada peluang untuk menyimpang dari kebenaran.

Berdasarkan uraian diatas maka hipotesis penelitian ini adalah :

: Gender berpengaruh signifikan terhadap kepatuhan wajib pajak.

: Gender tidak berpengaruh signifikan terhadap kepatuhan wajib Pajak.

: Tingkat Pendidikan berpengaruh signifikan terhadap kepatuhan Wajib Pajak.

: Tingkat Pendidikan tidak berpengaruh signifikan terhadap kepatuhan Wajib Pajak.

\subsection{Penelitian Terdahulu}

1. Debbianita dan Verani Carolina (2013) dengan judul Analisis Pengaruh Tingkat Tax Knowledge dan Gender terhadap Tax Compliance: Studi Kasus Pada Wajib Pajak Orang Pribadi di Bandung. Dengan menggunakan metode Analysis of Variance (ANOVA). Hasil Penelitian menyatakn bahwa gender adalah salah satu factor yang secara signifikan mempengaruhi perilaku Kepatuhan wajib pajak. Dan tingkat tax knowledge tidak saling berinteraksi satu sama lain. Peneliti sebelumnya melakukan penelitian dengan variable yang sama yaitu Variabel Gender dan Tax Compliance (Kepatuhan Pajak). Peneliti sebelumnya juga meneliti variabel Tax knowledge (pengetahuan pajak) dan melakukan penelitian di objek yang berbeda.

2. Dewi Fitriyani, Eko Prasetyo, Reni Yustien, Achmad Hizazi (2014) dengan judul Pengaruh Gender, Latar Belakang Pekerjaan, dan Tingkat Pendidikan terhadap Kepatuhan Wajib Pajak. Metode yang digunakan yaitu Metode Kuantitatif. Hasil penelitian ini menunjukkan bahwa, gender tidak mempengaruhi kepatuhan wajib pajak. Latar belakang pekerjaan dan tingkat pendidikan memiliki pengaruh langsung terhadap kepatuhan wajib pajak. Peneliti sebelumnya melakukan penelitian dengan variable yang sama yaitu Gender dan Tingkat Pendidikan. Perbedaan yang ditemukan dalam penelitian sebelumnya terdapat pada jumlah variable yang diteliti dan objek penelitian. 


\section{METODE PENELITIAN}

\subsection{Jenis Penelitian}

Penelitian ini menggunakan metode penelitian kuantitatif dalam bentuk penelitian survey. Metode penelitian kuantitatif menurut Sugiyono (2013:13) adalah sebagai metode penelitian yang berlandaskan pada firasat positivisme, digunakan untuk meneliti pada populasi atau sampel tertentu, teknik pengambilan sampel biasanya digunakan secara random, pengumpulan data menggunakan instrument penelitian, analisa data bersifat kuantitatif/statistic dengan tujuan untuk menguji hipotesis yang telah ditetapkan.

\subsection{Tempat dan Waktu Penelitian}

Penelitian ini dilakukan di Kantor Pelayanan Pajak Pratama Tahuna Jalan Tatehe No.62, Santiago, Tahuna, Kabupaten Kepulauan Sangihe, Sulawesi Utara. Periode penelitian dimulai dari akhir bulan Juni sampai Juli 2017.

\subsection{Sampel dan Teknik Pengumpulan Sampel}

Anggota-anggota populasi yang terpilih untuk dilibatkan dalam penellitian, baik untuk diamati, diberi perlakuan, maupun dimintai pendapat tentang yang sedang diteliti disebut sampel (Indrawati, 2015:164). Teknik sampling yang digunakan dalam penelitian ini adalah Purposive Sampling yaitu teknik pengambilan sampel sumber data dengan pertimbangan tertentu (Sugiyono, 2013:218-219).

Teknik pengambilan sampel Wajib Pajak yaitu dengan membagikan 60 kuesioner kepada Wajib Pajak Orang Pribadi yang ditemui di Kantor Pelayanan Pajak Pratama Tahuna yang bersedia mengisi kuesioner penelitian.

\subsection{Metode Analisis}

Penelitian ini menggunakan alat analisis Analysis of Variance (ANOVA) dengan menggunakan SPSS. ANOVA merupakan metode untuk mengkaji hubungan antara satu variabel dependen yang berbentuk metric dengan satu atau lebih variabel independen yang berbentuk non-metrik atau kategorial. Sebelum melakukan analisis data menggunakan ANOVA perlu dilakukan pengujian asumsi homogeneity of variance. Pengujian asumsi homogeneity of variance dilakukan untuk memastikan bahwa sebelum dilakukan pengujian ANOVA, variabel dependen memiliki varians yang sama (tidak berbeda) dalam setiap kategori variabel independen (Ghozali, 2016). Dengan demikian, hipotesis dari pengujian ini adalah:

- $\mathrm{H}_{0}$ : Tidak terdapat perbedaan tingkat kepatuhan wajib pajak berdasarkan tingkat gender dan latar belakang pendidikan.

- $\mathrm{H}_{\mathrm{a}}$ : Terdapat perbedaan tingkat kepatuhan wajib pajak berdasarkan tingkat gender dan latar belakang pendidikan.

- Keputusan untuk menerima $\mathrm{H}_{0}$ antara lain dengan membandingkan nilai sig. dengan tingkat signifikasi $\alpha=0,05$. Diteria $\mathrm{H}_{0}$ apabila nilai sig. $>\alpha$.

\section{HASIL ANALISIS DAN PEMBAHASAN \\ 4.1. Hasil Penelitian \\ 4.1.1. Deskripsi Data}

Penelitian ini menyebarkan 60 kuesioner kepada responden namun hanya 51 kuesioner yang dapat diolah. Hal ini dikarenakan, terdapat 9 kuesioner yang tidak diisi secara lengkap dan jelas yang dapat menggangu hasil analisis data. Adapun jumlah Wajib Pajak yang terdaftar pada KPP Pratama Tahuna tahun 2017 sebanyak 28.867 wajib pajak yang terdiri dari $15.036(52,09 \%)$ wajib pajak laki-laki dan 13.831 (47,91\%) wajib pajak perempuan.

Responden dalam penelitian ini berjumlah 51 responden yang terdiri dari 32 atau $(62,74 \%)$ wajib pajak laki-laki, dan 19 atau $(37,25 \%)$ wajib pajak perempuan, serta 17 atau $(33,33 \%)$ wajib pajak berpendidikan SMA, 7 atau $(13,72 \%)$ wajib pajak berpendidikan 
Diploma, 24 atau (47,05\%) wajib pajak berpendidikan Sarjana, dan 3 atau $(5,88 \%)$ wajib pajak berpendidikan Magister.

\subsubsection{Uji Asumsi}

\subsubsection{Uji Normalitas}

Menurut Sujarweni (2015:52), data yang baik dan layak digunakan dalam penelitian adalah data yang memiliki distribusi normal. Normalitas data dapat dilihat dengan menggunakan uji Normal Kolmogorov-Smirnov (K-S). Pengambilan keputusan yang menyatakan data berdistribusi normal berdasarkan:

Jika nilai Asymp. Sig. (2-tailed) > 0,05 maka data berdistribusi normal

Jika nilai Asymp. Sig. (2-tailed) < 0,05 maka data tidak berdistribusi normal

Tabel 4.2 Uji Normalitas

One-Sample Kolmogorov-Smirnov Test

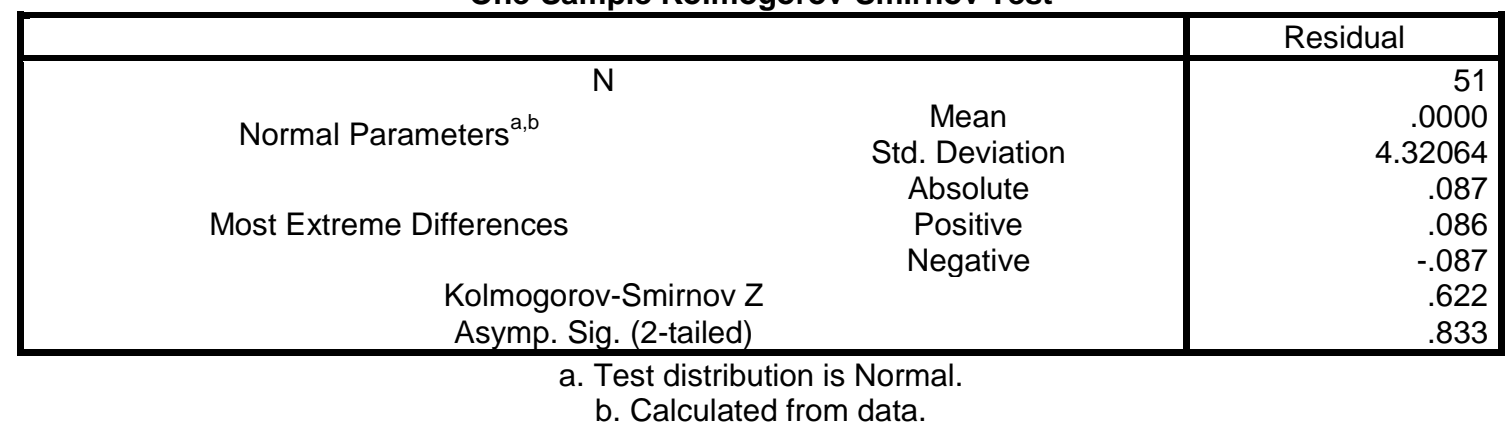

Sumber : Output SPSS 2017

Hasil pengujian Kolmogorov-Smirnov yang disajikan pada table 4.2 menunjukkan bahwa nilai Asymp. Sig. (2-tailed) >0,05 yaitu 0,833. Sehingga dapat disimpulkan bahwa data dalam penelitian ini berdistribusi normal.

\section{Gambar 4.1 Normality Residual Plot}

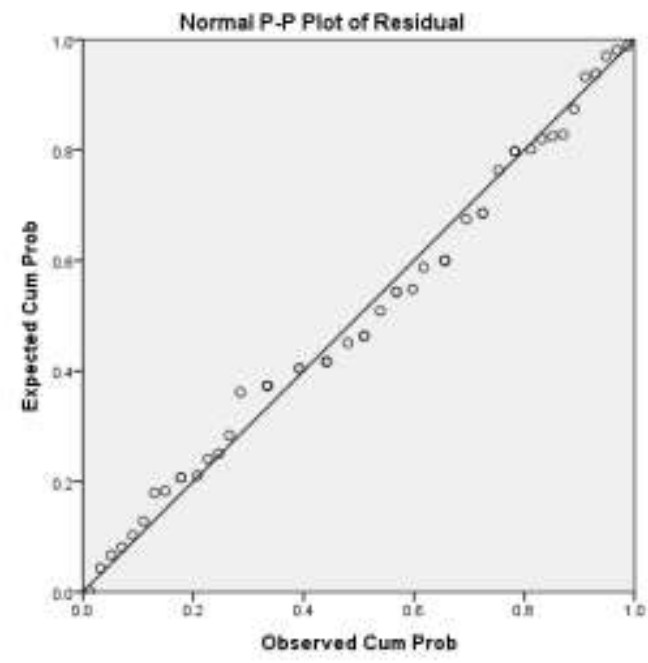

Sumber : Output SPSS 2017

Tampak secara visual gambar 4.1, titik-titik residual mengikuti pola garis lurus. 


\subsubsection{Uji Validitas dan Reliabilitas}

\subsubsection{Uji Validitas}

Untuk mengukur valid atau tidaknya setiap butir pertanyaan dalam suatu kuesioner dapat diketahui dengan cara hasil $\mathrm{r}$ hitung dibandingkan dengan $\mathrm{r}$ table dimana degree of freedom $(\mathrm{df})=\mathrm{n}-2$ dengan dig 5\%. Jika $\mathrm{r}$ table $<\mathrm{r}$ hitung maka valid (Sujarweni, 2015:192).

Dengan jumlah responden sebanyak 51 maka nilai $\mathrm{r}$ tabel dapat diperoleh melalui tabel $\mathrm{r}$ product moment pearson dengan df (degree of freedom) $=\mathrm{n}-2$, jadi $\mathrm{df}=51-2=49$, maka $r$ tabel adalah 0,235. Butir pertanyaan dikatakan valid jika nilai $r$ hitung $>r$ tabel, dilihat dari Corrected Item-Total Correlation.

Tabel 4.3 Hasil Uji Validitas Kuesioner

\begin{tabular}{|c|c|c|c|}
\hline Variabel & $\begin{array}{c}\text { Corrected Item- } \\
\text { Total } \\
\text { Correlation }\end{array}$ & r tabel & Keterangan \\
\hline Pertanyaan 1 & 0,302 & 0,235 & Valid \\
\hline Pertanyaan 2 & 0,373 & 0,235 & Valid \\
\hline Pertanyaan 3 & 0,445 & 0,235 & Valid \\
\hline Pertanyaan 4 & 0,412 & 0,235 & Valid \\
\hline Pertanyaan 5 & 0,272 & 0,235 & Valid \\
\hline Pertanyaan 6 & 0,272 & 0,235 & Valid \\
\hline Pertanyaan 7 & 0,435 & 0,235 & Valid \\
\hline Pertanyaan 8 & 0,431 & 0,235 & Valid \\
\hline Pertanyaan 9 & 0,480 & 0,235 & Valid \\
\hline Pertanyaan 10 & 0,483 & 0,235 & Valid \\
\hline
\end{tabular}

Sumber : Data Kuesioner, diolah 2017

Dengan demikian, dapat disimpulkan bahwa semua pertanyaan dinyatakan valid.

\subsubsection{Uji Reliabilitas}

Uji reliabilitas dapat dilihat pada nilai Cronbach's Alpha, jika nilai Alpha > 0,60 maka kontruk pertanyaan yang merupakan dimensi variabel adalah reliable (Sujarweni, 2015:199).

Tabel 4.4 Uji Reliabilitas

Reliability Statistics

\begin{tabular}{|r|r|r|}
\hline Cronbach's Alpha & $\begin{array}{c}\text { Cronbach's Alpha } \\
\text { Based on } \\
\text { Standardized Items }\end{array}$ & N of Items \\
\hline .729 & .730 & 10 \\
\hline
\end{tabular}

Sumber : Output SPSS 2017

Hasil pengujian menunjukkan nilai Cronbach's Alpha sebesar 0,729 > 0,60. Dengan demikian dapat disimpulkan bahwa instrument penelitian telah reliable.

\subsubsection{Uji Homogenity of Variance}

Menurut Ghozali (2016) pengujian asumsi homogeneity of variance dilakukan untuk menunjukkan bahwa variabel dependen memiliki varians yang sama dalam setiap kategori variabel dependen. Dengan hipotesis:

$\mathrm{H}_{0}$ : Tidak terdapat perbedaan tingkat kepatuhan wajib pajak berdasarkan gender dan tingkat pendidikan.

$\mathrm{H}_{\mathrm{a}}$ : Terdapat perbedaan tigkat kepatuhan wajib pajak berdasarkan gender dan tingkat pendidikan. 


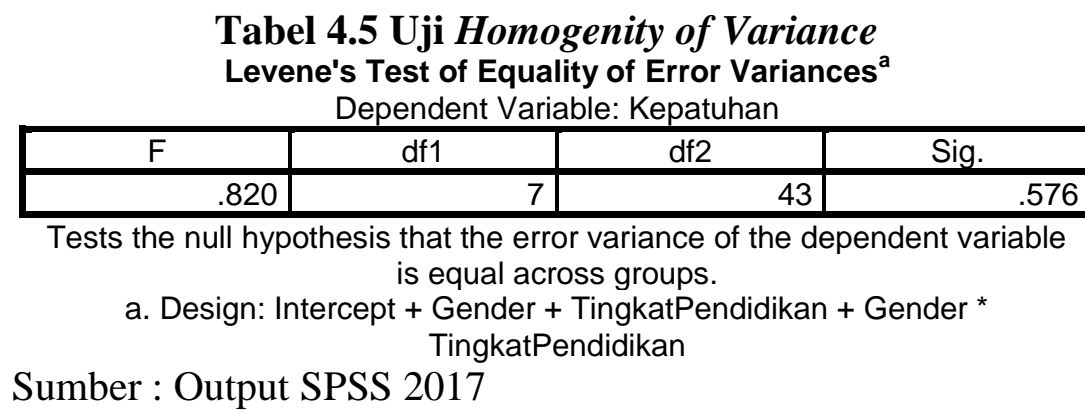

Keputusan untuk menerima $\mathrm{H}_{0}$ apabila nilai sig. $>\alpha$, dengan tingkat signifikasi $\alpha=$ 0,05. Dari hasil pengelolaan data dalam tabel 4.5 diperoleh nilai sig. 0,576. Oleh karena sig. $>0,05$ maka $\mathrm{H}_{0}$ diterima. Sehingga analisis selanjutnya bisa dilakukan.

\subsubsection{Uji ANOVA}

\section{Tabel 4.6 Uji ANOVA}

Tests of Between-Subjects Effects

Dependent Variable: Kepatuhan

\begin{tabular}{|c|r|r|r|r|r|}
\hline Source & $\begin{array}{c}\text { Type III Sum of } \\
\text { Squares }\end{array}$ & \multicolumn{1}{c|}{$\mathrm{df}$} & Mean Square & $\mathrm{F}$ & Sig. \\
\hline Corrected Model & $582.824^{\mathrm{a}}$ & 7 & 83.261 & 5.123 & .000 \\
Intercept & 14887.146 & 1 & 14887.146 & 915.985 & .000 \\
Gender & .994 & 1 & .994 & .061 & .806 \\
TingkatPendidikan & 456.113 & 3 & 152.038 & 9.355 & .000 \\
Gender * TingkatPendidikan & 43.541 & 3 & 14.514 & .893 & .452 \\
Error & 698.862 & 43 & 16.253 & & \\
Total & 31285.000 & 51 & & & \\
Corrected Total & 1281.686 & 50 & & & \\
\hline
\end{tabular}

a. R Squared $=.455$ (Adjusted R Squared $=.366$ )

Sumber : Output SPSS 2017

Hipotesis yang akan diuji antara lain:

1. $\mathrm{H}_{01}$ : Tidak terdapat pengaruh langsung gender pada kepatuhan wajib pajak

$\mathrm{H}_{\mathrm{a} 1}$ : Terdapat pengaruh langsung gender pada kepatuhan wajib pajak

Penerimaan $\mathrm{H}_{01}$ yaitu jika nilai sig. $>\alpha$, dimana $\alpha=0,05$. Hasil penelitian (dalam tabel 4.6), diketahui memiliki nilai sig. 0,806 >0,05, maka $\mathrm{H}_{01}$ diterima dan $\mathrm{H}_{\mathrm{a} 1}$ ditolak. Hal ini menunjukkan gender (laki-laki atau perempuan) tidak terdapat pengaruh langsung terhadap kepatuhan wajib pajak.

Hasil ini mendukung penelitian Kasipillai dan Jabbar (2006) dan Fitriyani, Prasetyo, Yustien dan Hizazi (2014) yang menemukan, bahwa baik laki-laki maupun perempuan memiliki sikap yang sama terhadap kepatuhan wajib pajak. Namun tidak dapat mendukung penelitian Debbianita dan Carolina (2013) dan Hai dan See (2011), yang menyatakan gender berpengaruh terhadap kepatuhan wajib pajak.

2. $\mathrm{H}_{02}$ : Tidak terdapat pengaruh langsung tingkat pendidikan pada kepatuhan wajib pajak

$\mathrm{H}_{\mathrm{a} 2}$ : Terdapat pengaruh langsung tingkat pendidikan pada kepatuhan wajib pajak

Penerimaan $\mathrm{H}_{02}$ yaitu jika nilai sig. $>\alpha$, dimana $\alpha=0,05$. Hasil penelitian (dalam tabel 4.6) diketahui memiliki nilai sig. $0,000>0,05$, maka $\mathrm{H}_{02}$ ditolak dan $\mathrm{H}_{\mathrm{a} 2}$ diterima. Hal ini menunjukkan bahwa tingkat pendidikan terdapat pengaruh langsung terhadap kepatuhan wajib pajak.

Mendukung penelitian terdahulu oleh Dewi Firiani, dkk (2014) yang menemukan bahwa tingkat pendidikan memiliki pengaruh langsung terhadap kepatuhan wajib pajak. Secara 
deskriptif, semakin tinggi tingkat pendidikan wajib pajak orang pribadi, semakin tinggi perilku untuk patuh.

3. $\mathrm{H}_{03}$ : Tidak terdapat interaksi antara gender dan tingkat pendidikan dalam memengaruhi kepatuhan wajib pajak

$\mathrm{H}_{\mathrm{a} 3}$ : Terdapat interaksi antara gender dan tingkat pendidikan dalam memengaruhi kepatuhan wajib pajak

Penerimaan $\mathrm{H}_{02}$ yaitu jika nilai sig. $>\alpha$, dimana $\alpha=0,05$. Hasil penelitian (dalam tabel 4.6), diketahui memiliki nilai sig. 0,452 >0,05, maka $\mathrm{H}_{02}$ diterima dan $\mathrm{H}_{\mathrm{a} 2}$ ditolak. Hal ini menunjukkan bahwa tidak terdapat interaksi antara gender dan tingkat pendidikan dalam memengaruhi kepatuhan wajib pajak.

\section{KESIMPULAN DAN SARAN}

\subsection{Kesimpulan}

Berdasarkan hasil penelitian, kesimpulan yang dapat ditarik yaitu sebagai berikut :

1. Tidak terdapat pengaruh langsung Gender pada Kepatuhan Wajib Pajak Orang Pribadi yang terdaftar pada KPP Pratama Tahuna berdasarkan hasil uji ANOVA dengan nilai signifikasi $0,806>0,05 . \mathrm{H}_{0}$ diterima dan $\mathrm{H}_{\mathrm{a}}$ ditolak.

2. Terdapat pengaruh langsung Tingkat Pendidikan pada Kepatuhan Wajib Pajak Orang Pribadi yang terdaftar pada KPP Pratama Tahuna berdasarkan hasil uji ANOVA dengan nilai signifikasi $0,000>0,05 . \mathrm{H}_{0}$ ditolak dan $\mathrm{H}_{\mathrm{a}}$ diterima.

3. Tidak terdapat interaksi antar gender dan tingkat pendidikan dalam memengaruhi Kepatuhan Wajib Pajak Orang Pribadi yang terdaftar pada KPP Pratama Tahuna berdasarkan hasil uji ANOVA dengan nilai signifikasi 0,452>0,05. $\mathrm{H}_{0}$ diterima dan $\mathrm{H}_{\mathrm{a}}$ ditolak.

\subsection{Saran}

Adapun saran untuk:

1. KPP Pratama Tahuna. Dari penelitian yang dilakukan dapat diidentifikasi bahwa tingkat pendidikan memiliki pengaruh langsung terhadap Kepatuhan Wajib Pajak Orang Pribadi yang terdaftar pada KPP Pratama Tahuna. Wajib Pajak yang kurang patuh mungkin dikarenakan mereka tidak memiliki pemahaman yang cukup baik tentang peraturan dan kebijakan perpajakan. Upaya yang dapat dilakukan Direkur Jendral Pajak yaitu dengan mengadakan seminar, penyuluhan, sosialisasi.

2. Bagi peneliti selanjutnya hendaknya menambahkan lagi variabel lain yang dapat mempengaruhi tingkat kepatuhan Wajib Pajak seperti latar belakang pekerjaan Wajib Pajak, Tingkat Penghasilan, dan pemahaman Wajib Pajak tentang peraturan perpajakan.

\section{DAFTAR PUSTAKA}

Agoes, Sukrisno dan Trisnawati, Estralita. 2013. Akuntansi Perpajakan. Edisi-3. Jakarta: Salemba Empat.

Al-Mamun, Abdullah, Harry Entebang, Shazali Abu Mansor, Qaiser Rafique Yasser, dan Thurai Murugan Nathan. 2014. The Impact of Demografic Factors on Tax Compliance Attitude and Behaviors in Malaysia. Journal of Finance, Accounting and Management. 5(1), pp. 109-124.

Amilin dan Fanny Yusronillah. 2009. Analisis Pengaruh Tingkat Pendidikan dan Jenis Pekerjaan Wajib Pajak terhadap Motivasi dalam Memenuhi Kewajiban Pajak. JMK Vol.7 No.3.

Centre for Tax Policy and Administration. 2004. Compliance. Organisation for Economic Cooperation and Development. 
Dewi Fitriyani, Eko Prasetyo, Reni Yustien, Achmad Hizazi. 2014. Pengaruh Gender, Latar Belakang Pekerjaan, dan Tingkat Pendidikan Terhadap Kepatuhan Wajib Pajak. Universitas Jambi. Jurnal InFestasi Vol.10 No. 2.

Debbianita dan Verani Carolina. 2013. Analisis Pengaruh Tingkat Tax Knowledge dan Gender terhadap Tax Compliance: Studi Kasus Pada Wajib Pajak Orang Pribadi di Bandung. Jurusan Akuntansi Universitas Kristen Maranatha Bandung

Eka Maryati. 2014. Pengaruh Sanksi Pajak, Motivasi dan Tingkat pendidikan Terhadap Kepatuhan Wajib Pajak. Skripsi. Jurusan Akuntansi Fakultas Ekonomi. Universitas Maritim raja Ali Haji. Tanjungpinang.

Ganda Pasaribu, Christine Tjen. 2016. Dampak Faktor-Faktor Demografi Terhadap Kepatuhan Perpajakan di Indonesia. Skripsi. Universitas Indonesia. Berkala Akuntansi dan Keuangan Indonesia. Vol.1. No.2: 145-162.

Ghozali, Imam. 2016. Aplikasi Analisis Multivariete dengan Program IBM SPSS 21. Semarang: Badan Penerbit Universitas Diponegoro.

Indrawati. 2015. Metode Penelitian Manajemen dan Bisnis. Refika Aditama. Bandung.

Kasipillai, Jeyapalan and Hijattullah Abdul Jabbar. 2006. Gender and Ethnicity Differences in Tax Compliance. Asian Academy of Management Journal Vol.11 No.2.

Keputusan Menteri Keuangan No. 544/KMK.04/2000 tentang Kepatuhan Wajib Pajak.

Lubis. I, 2015, Mahir Akuntansi Pajak Terapan, edisi ke-1, Yogyakarta : Andi

Mardiasmo. 2016. Perpajakan Edisi Revisi 2016. ANDI. Yogyakarta.

Peraturan Menteri Keuangan Nomor 74/PMK.03/2012 tentang Tata Cara Penetapan Wajib Pajak Dengan Kriteria Tertentu Dalam Rangka Pengembalian Pendahuluan Kelebihan Pembayaran Pajak.

Pontoh, Fransiska Imelda, Inggriani Elim, dan Novi S. Budiarso. 2017. Analisis FaktorFaktor yang Mempengaruhi Wajib Pajak Menggunakan Jasa Konsultan Pajak. Universitas Sam Ratulangi Manado. Jurnal Riset Ekonomi, Manajemen, Bisnis Dan Akuntansi 5(2).

Sugiyono. 2013. Metode Penelitian Pendidikan Pendekatan Kuantitatif, Kualitatif, dan R\&D. Bandung: Alfabeta.

Sujarweni. 2015. SPSS Untuk Penelitian. Pustaka Baru Press. Yogyakarta.

Supriyati dan Hidayati, Nur. 2014. Pengaruh Pengetahuan Pajak dan Persepsi Wajib Pajak terhadap Kepatuhan Wajib Pajak. Akuntansi dan Teknologi Informasi Vol.7 No.1.

Teik Hai dan Meng See. 2011. Behavioral Intention of Tax Non-Compliance among SoleProprietors in Malaysia. Centre for Promoting Ideas. USA.

Undang-Undang Republik Indonesia No. 20 Tahun 2003 tentang Sistem Pendidikan Nasional.

Republik Indonesia. Undang-Undang Nomor 28 Tahun 2007: Tentang Perubahan Ketiga atas UU RI No. 6 Tahun 1983 tentang Ketentuan Umum dan Tata Cara Perpajakan.

Sumarsan,Thomas. 2014. Perpajakan Indonesia. Edisi empat. Indeks. Jakarta. 